\title{
PENGARUH KEMAMPUAN MENGHAFAL AL-QUR'AN DAN SIKAP SISWA TERHADAP HASIL BELAJAR MATEMATIKA
}

\section{Sita Husnul Khotimah}

Sekolah Tinggi Agama Islam ALHIKMAH Jakarta sita_kh81@yahoo.com

\section{Absract}

The purpose of this study is to determine the effect of ability to memorize al-Qur'an, students' attitude, and interactions both of them towards students' learning outcomes in mathematics. The research method used is the correlational survey method, the number of sample are 60 students from two classes who conduct memorization of Al-Qur'an. Data collection was done by using questionnaire distribution and test technique. Data analysis using correlation analysis and multiple regression methods.

The statistical test used was t test and F test. Data analysis used correlation and regression techniques (simple \& plural). From the research results found that: (1) there is a significant influence between the ability to read Al-Qur'an towards mathematics learning outcomes $(r=0.883$ and $\hat{Y}=1,276+1,182 X 1)$. (2) there is significant influence between students' attitude towards mathematics learning outcomes $(r=0.876$ and $\hat{Y}=0.509+$ $0.138 X 2)$. (3) there is significant influence between the ability to memorize Al-Qur'an and students' attitude towards mathematics learning outcomes $(r=0.893$ and $\hat{Y}=0.183+0.062 X 1+0.689 X 2)$.

Keywords: Memorize al-Qur'an, Student's Attitude, Matematics Learning Outcame. 


\section{Abstrak}

Tujuan dari penelitian ini adalah untuk mengetahui pengaruh kemampuan menghafal al-Qur'an, sikap siswa dan interaksi keduanya terhadap hasil belajar matematika siswa. Metode penelitian yang digunakan adalah metode survey korelasional, sampel berjumlah 60 siswa dari dua kelas yang menerapkan hafalan al-Qur'an. Pengumpulan data dilakukan dengan menggunakan teknik penyebaran angket dan teknik tes. Analisa data dengan menggunakan metode analisis korelasi dan regresi ganda. Uji statistik yang digunakan adalah uji t dan uji F. Analisis data menggunakan teknik korelasi dan regresi (sederhana \& jamak). Dari hasil penelitian ditemukan bahwa: (1) terdapat pengaruh yang berarti antara kemampuan membaca al-Qur'an terhadap hasil belajar matematika $(r=0,883$ dan $\hat{Y}=1.276+$ 1,182X $)$. (2) terdapat pengaruh yang berarti antara sikap siswa terhadap hasil belajar matematika $(r=0,876$ dan $\hat{Y}=0.509+$ $\left.0,138 X_{2}\right)$. (3) terdapat pengaruh yang berarti antara kemampuan menghafal Al-Qur'an dan sikap siswa terhadap hasil belajar matematika $\left(r=0,893\right.$ dan $\left.\hat{Y}=0.183+0,062 X_{1}+0,689 X_{2}\right)$.

Kata Kunci: Menghafal al-Qur'an, Sikap Siswa, Hasil Belajar Matematika. 


\section{A. PENDAHULUAN}

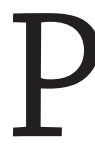
endidikan merupakan suatu hal yang penting bagi kehidupan manusia, karena dengan pendidikan manusia akan terbuka cakrawala intelektual serta spiritualnya. Pentingnya pendidikan bukanlah sebatas bagi tumbuh kembang secara jasmani atau fisik manusia saja, tetapi juga menyangkut pendidikan bagi tumbuh kembang rohaninya. Pendidikan sangat dibutuhkan sejak dini, karena dengan pendidikan dapat dijadikan sebagai pedoman hidup hingga menuju masa tuanya.

Masalah pokok yang dihadapi dunia pendidikan di Indonesia adalah rendahnya kualitas pendidikan pada setiap jenjang dan satuan pendidikan. Banyak faktor yang menyebabkan rendahnya kualitas pendidikan di Indonesia. Salah satunya adalah kurikulum yang selama ini selalu bersifat sentralistik, menafikan keragaman dan hanya berorientasi pada penguasaan materi pelajaran (ranah kognitif). Mata pelajaran yang memiliki penekanan pada ranah kognitif salah satunya adalah matematika. Penguasaan ilmu matematika mutlak dimiliki oleh setiap orang, mengingat matematika merupakan induk ilmu pengetahuan. Akan tetapi dalam kenyataannya matematika belum menjadi pelajaran yang difavoritkan, bahkan mata pelajaran ini kerap dianggap sulit dan menakutkan bagi sebagian besar siswa.

Belajar matematika sangat memerlukan konsentrasi, karena digunakan untuk memahami materi dan penjelasan dari konsep, rumus-rumus, serta soal-soal yang diberikan guru.

Hal tersebut dikarenakan, apabila siswa tidak berkonsentrasi ketika pembelajaran berlangsungmakasiswa tersebutakankesulitan untuk mengerjakan soal yang diberikan dan akan mempengaruhi hasil belajar matematikanya. Hasil belajar merupakan salah satu bukti yang menunjukkan kemampuan atau keberhasilan seseorang melakukan proses belajar sesuai dengan bobot atau nilai yang berhasil diraihnya, dengan demikian hasil belajar merupakan hasil maksimum yang dicapai seseorang setelah melakukan proses 
belajar. ${ }^{1}$ Akan tetapi, kenyataan yang terjadi adalah banyak siswa yang kehilangan konsentrasi belajarnya dalam pembelajaran matematika. Konsentrasi merupakan induk dari semua aktifitas pembelajaran, namun ironisnya sangat banyak individu pembelajar yang tidak atau belum mampu berkonsentrasi. Ketidakberadaan pihak yang mampu mengajari mereka terkait dengan konsentrasi, baik guru maupun orang tua, turut menyebabkan hal ini.

Alternaif solusi yang dilakukan beberapa Sekolah Dasar (SD) dalam mengatasimasalahkonsentrasiadalah dengan menambahkan muatan mata pelajaran Tahfidz (menghafal al-Qur'an). Melalui hafalan al-Qur'an diharapkan siswa terbiasa berkonsentrasi, sehingga berdampak pada konsentrasi terhadap mata pelajaran yang lain. Pada kasus yang ada, siswa masih mengalami banyak kesulitan dalam menghafal materi matematika. Bagi siswa muslim, ada kemungkinan menghafal al-Qur'an dapat dijadikan pemicu dalam kemampuan menghafal suatu hal. Sehingga, dengan kebiasaan menghafal al-Qur'an siswa dapat mengingat dengan baik. Hakikat Hafalan adalah bertumpu pada ingatan, lama waktu utuk merespon, menerima dan memproduksi kembali tergantung pada masin-masing orang. Karena kekuatan menghafal masing-masing orang sudah pasti berbeda. Melatih anak menghafal al-Qur'an malah dapat meningkatkan kecerdasannya. Ternyata, menghafal al-Qur'an dapat mencerdaskan otak. ${ }^{2}$ Menghafal al-Qur'an berarti membaca al-Qur'an secara berulang-ulang sehingga hafal dari satu ayat ke ayat berikutnya, satu surat ke surat berikutnya sehingga dapat diucapkan dengan baik tanpa melihat al-Qur'an. ${ }^{3}$

Di samping hal-hal tersebut di atas, sikap siswa dalam menjalankan proses pembelajaran juga sudah selayaknya menjadi perhatian para pendidik. Sikap yang baik dan cenderung positif pada dasarnya memberikan dampak yang cukup signifikan apabila

1 Arif Rohman, Memahami Pendidikan dan Ilmu Pendidikan, (Yogyakarta: Laksbang Mediatama, 2009), h. 223.

2 Neni, "Pengaruh Menghafal al-Quran Terhadap Kecerdasan Emosional Santri Di Pondok Pesantren al-Quran Muhammad Thoha Alfasyni Bogor" dalam Tadbir Muwahhid, Vol. 4, No. 1, 2017.

3 Anwar, K., \& Hafiyana, M. "Implementasi Metode ODOA (One Day One Ayat) dalam Meningkatkan Kemampuan Menghafal Al-Qur'an”, dalam Jurnal Pendidikan Islam Indonesia, Vol. 2, No. 2, 2018, h. 181-198. 
dilihat keterkaitannya dengan hasil belajar siswa. Sikap siswa terhadap matematika dapat didefinisikan sebagai kecenderungan yang dipelajari individu untuk merespon secarapositif atau negatif terhadap matematika. ${ }^{4}$ Matematika sebagai mata pelajaran yang konkret membutuhkan sebuah perhatian dan pemahaman akan konsep yang cukup dalam, sehingga tidak dapat dipungkiri bahwa apabila siswa tertarik atau bersikap positif terhadap mata pelajaran ini bukan tidak mungkin siswa tersebut mendapatkan hasil belajar yang cukup memuaskan. Dengan adanya sikap siswa pada matematika, tidak menutup kemungkinan mempengaruhi hasil belajar matematika. Artinya dengan adanya sikap siswa pada matematika hasil belajar matematika bisa semakin baik atau sebaliknya. ${ }^{5}$

Berdasarkan uraian di atas, maka diperoleh rumusan masalah sebagai berikut: (1) Apakah terdapat pengaruh kemampuan menghafal al-Qur'an terhadap hasil belajar matematika siswa (2) Apakah terdapat pengaruh sikap siswa terhadap hasil belajar matematika (3) Apakah terdapat pengaruh interaksi antara kemampuan menghafal al-Qur'an dan sikap siswa terhadap hasil belajar matematika.

\section{B. METODE PENELITIAN}

Penelitian ini dilakukan di Madrasah Ibtidaiyah Terpadu (MIT) Nurul Falah Depok dengan populasi penelitian seluruh siswa kelas V, dengan jumlah sampel 50 siswa dari dua kelas. Berdasarkan fokus permasalahan dan tujuan yang hendak dicapai, penelitian ini tergolong ke dalam metode survey karena melakukan pengukuran terhadap hal-hal yang nyata seperti mengukur kemampuan menghafal al-Qur'an, sikap siswa pada matematika dan hasil belajar matematika. Penelitian ini menggunakan

4 Bassette, L. P. " An assessment of the attitudes and outcomes ofstudents enrolled in developmental basic mathematics classes atPrince George's community college” dalam Doctoral dissertation, VirginiaPolytechnic Institute and State University, 2004. Diunduh dari http://academia. edu/ pada 27 Januari 2020.

5 Susilo, T. A. B., \& Agustin, I. "Pengaruh Sikap Siswa pada Matematika terhadap Hasil Belajar Matematika di SMP” dalam Jurnal Pendidikan Matematika, Vol. 3, No. 1, 2015, h. 9-16. 
teknik analisis korelasional yakni teknik yang dirancang untuk mengetahui seberapa besar pengaruh antara variabel bebas dengan variabel terikat. teknik pengumpulan data dalam penelitian ini menggunakan instrumen dalam bentuk kuisioner dan tes. Teknik pengumpulan data untuk variabel kemampuan menghafal alQur'an yaitu dengan menggunakan daftar nilai hafalan al-Qur'an (Tahfidz), sikap siswa dengan menggunakan kuisioner skala sikap dan untuk variabel hasil belajar matematika dengan menggunakan tes akademik yang mengandung materi matematika kelas V MI semester I. Teknik analisa data menggunakan pengujian korelasi ganda dengan program SPSS 22.

Gambar 1. Konstelasi Permasalahan Penelitian

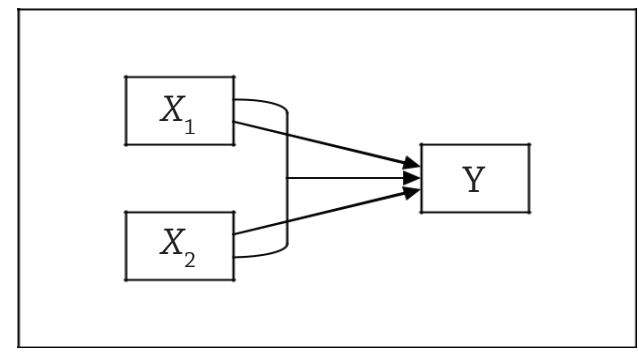

\section{HASIL DAN PEMBAHASAN}

\section{Hasil Penelitian}

a. Uji Normalitas

Hasil uji normalias menyatakan sebaran sampel mengikuti distribusi normal dapat diterima, karena nilai Sig > 0,05. Berdasarkan data tersebut, maka dapat diambil kesimpulan bahwa sebaran skor variabel hasil belajar matematika dengan nilai Sig 0,220, variabel kemampuan menghafal al-Qur'an dengan nilai Sig. 0,666 dan sikap siswa dengan nilai Sig. 0,291 berasal dari populasi berdistribusi normal.

b. Uji Linieritas

Dari hasil uji linieritas bahwa $\mathrm{F}_{\text {hitung }}<\mathrm{F}_{\text {table }}$ yaitu 
$191.882<3.090$ maka garis regresi tersebut linier karena nilai $\mathrm{F}_{\text {hitung }}$, sedangkan nilai $\mathrm{F}_{\text {tabel }}$ untuk taraf nyata $\alpha=5 \%$ $(0,05) \mathrm{n}=50$ adalah 3.090 maka $\mathrm{F}_{\text {hitung }}<\mathrm{F}$ tabel yang berarti bahwa garis regresi tersebut adalah linier.

c. Uji Hipotesis

1) Kemampuan menghafal al-Qur'an $\left(X_{1}\right)$ dan sikap siswa $\left(\mathrm{X}_{2}\right)$ bersama-sama terhadap Hasil Belajar Matematika $(\mathrm{Y})$

Tabel ANOVA ganda antara $\mathrm{X}_{1}$ dan $\mathrm{X}_{2}$ terhadap $\mathrm{Y}$

\section{ANOVA $^{a}$}

\begin{tabular}{|l|l|l|l|l|c|c|}
\hline & \multicolumn{1}{|c|}{ Model } & \multicolumn{1}{c|}{ Sum of Squares } & Df & Mean Square & F & Sig. \\
\hline 1 & Regression & 1523.964 & 2 & 761.982 & 191.882 & $.000^{\mathrm{b}}$ \\
\hline & Residual & 385.196 & 97 & 3.971 & & \\
\hline & Total & 1909.160 & 99 & & & \\
\hline
\end{tabular}

Analisis korelasi ganda antara X1 dan X2 dengan Y menghasilkan koefisien korelasi ganda (Ry12) sebesar 0,893. Uji keberartian koefisien korelasi ganda menghasilkan nilai Fhitung sebesar 191.882 pada taraf Sig 0,000 yang berarti sangat signifikan. Dengan demikian nilai $191.882>$ 3.090. Hal ini menunjukkan bahwa ada pengaruh yang signifikan antara Kemampuan menghafal al-Qur'an (X1) dan sikap siswa (X2) terhadap hasil belajar matematika (Y). Pada kelompok siswa yang memiliki sikap positif, tidak ada perbedaan yang signifikan antara hasil belajar matematika siswa yang kemampuan menghafal al-Qur'annya begus dengan nilai rata-rata 85,25 dan yang hafalan al-Qur'annya kurang bagus dengan nilai 85,19 hampir sama dengan siswa yang kemampuan menghafal al-Qur'annya bagus. Dengan demikian artinya, untuk mereka yang memiliki sikap positif, sama efektifnya dalam pembelajaran matematika.

Penjelasan mengenai penemuan tersebut yaitu: Menurut Sudjana (2011), hasil belajar siswa pada 
hakikatnya adalah perubahan tingkah laku. Tingkah laku sebagai hasil belajar dalam pengertian yang luas mencakup bidang kognitif, afektif dan psikomotoris. Menurut Syah, ${ }^{6}$ faktor-faktor yang mempengaruhi belajar siswa yaitu faktor internal, eksternal dan pendekatanbelajar.Siswayangtelahmenyadaritugasnya sebagai pelajar seharusnya dapat memaksimalkan hasil belajarnya. Hasil belajar matematika siswa dapat dilihat apabila tujuan pembelajaran yang telah ditetapkan dapat dicapai oleh siswa, dan sebaliknya apabila siswa tidak dapat mencapai tujuan-tujuan dari pembelajaran dapat dipastikan hasil pembelajaran tidak tercapai. Berdasarkan studi yang dilakukan oleh Shaleh Bin Ibrahim Ashani dalam Ilmia, ${ }^{7}$ disimpulkan adanya korelasi positif antara kuantitas hafalan al-Qur'an dengan tingkat kesehatan mental dan psikologis siswa yang mempengaruhi pengembangan keterampilan siswa dan prestasi di sekolah. Sedangkan prestasi belajar di sekolah adalah penilaian hasil belajar siswa dalam jangka waktu tertentu yang dicatat dalam buku raport.

2) Pengaruh antara kemampuan menghafal al-Qur'an $\left(\mathrm{X}_{1}\right)$ dengan Hasil Belajar Matematika $(\mathrm{Y})$

Tabel ANOVA ganda antara $\mathrm{X}_{1}$ terhadap $\mathrm{Y}$

\section{ANOVA $^{a}$}

\begin{tabular}{|c|l|l|c|l|c|c|}
\hline \multicolumn{2}{|c|}{ Model } & Sum of Squares & Df & Mean Square & F & Sig. \\
\hline 1 & Regression & 1489.246 & 1 & 1489.246 & 347.562 & $.000^{\mathrm{b}}$ \\
\hline & Residual & 419.914 & 98 & 4.285 & & \\
\hline & Total & 1909.160 & 99 & & & \\
\hline
\end{tabular}

Analisis korelasi antara $\mathrm{X}_{1}$ dengan $\mathrm{Y}$ menghasilkan

6 M. Syah, M, Psikologi Belajar, (Jakarta: PT. Raja Grafindo Persada, 2003).

7 Ilmia, M., "Hubungan antara hafalan Al-Qur'an dengan prestasi belajar siswa kelas IV Sekolah Dasar Islam As-salam Malang", dalam Doctoral dissertation, Universitas Islam Negeri Maulana Malik Ibrahim, 2016. 
koefisien korelasi ganda $\left(\mathrm{Ry}_{12}\right)$ sebesar 0,883. Uji keberartian koefisien korelasi ganda menghasilkan nilai $\mathrm{F}_{\text {hitung }}$ sebesar 347,562 pada taraf Sig 0,000 yang berarti sangat signifikan. Hal ini menunjukkan bahwa ada pengaruh yang signifikan antara kemampuan menghafal Al-Qur'an $\left(\mathrm{X}_{1}\right)$ terhadap hasil belajar matematika (Y).

Penjelasan mengenai penemuan tersebut yaitu, Sa'dulloh ${ }^{8}$ menyatakan bahwa kemampuan menghafal al-Qur'an adalah kesanggupan, kecakapan dalam mengingat diluar kepala dengan cara membaca berulang-ulang al-Qur'an agar senantiasa ingat dalam rangka menjaga kemurnian al-Qur'an. Manfaat menghafal al-Qur'an dikemukakan oleh Jayanti, ${ }^{9}$ orang yang menghafal al-Qur'an akan mendapatkan anugerah dari Allah berupa ingatan yang tajam dan pemikiran yang cemerlang. Karena itu, para penghafal al-Qur'an lebih cepat mengerti, teliti, dan lebih hatihati karena banyak latihan untuk mencocokkan ayat serta membandingkannya dengan ayat lainnya. Hal ini memungkinkan siswa yang hafalan al-Qur'annya bagus lebih cermat dan teliti dalam belajar dan mengerjakan soal matematika, sehingga hasil belajar matematikanya bagus. Hal yang serupa juga diungkapkan Romi dan Arief, ${ }^{10}$ dengan hasil penelitian menunjukkan prestasi belajar matematika siswa yang mengikuti program menghafal al-Qur'an lebih tinggi daripada siswa yang tidak mengikuti program menghafal al-Qur'an dimana skor rata-rata sebesar 12,41 untuk siswa yang mengikuti program menghafal al-Qur'an dan 10,45 untuk siswa yang tidak mengikuti program menghafal al-Qur'an.

8 Sa'dulloh, Cara Praktis Menghafal Al-Qur'an, (Jakarta: Gema Insani, 2008), h. 9.

9 Jayanti, L. F. “Pengaruh Motivasi Menghafal al-Qur'an terhadap Prestasi Belajar Siswa Mata Pelajaran al-Qur'an Hadist MA Darul Falah Bendiljati Kulon”, 2019.

10 Romi, R., Arief, Y., \& Siregar, J. "Perbedaan Prestasi Belajar Matematika Antara Siswa Yang Mengikuti Dan Tidak Mengikuti Program Menghafal Al-Qur'an” dalam An-Nafs, Vol. 12, No. 1, 2018, h. 1-11. 
3) Pengaruh antara sikap siswa $\left(\mathrm{X}_{2}\right)$ dengan Hasil Belajar Matematika (Y).

Analisis korelasi antara $\mathrm{X}_{2}$ dengan $\mathrm{Y}$ menghasilkan koefisien korelasi ganda $\left(\mathrm{Ry}_{12}\right)$ sebesar 0,876. Uji keberartian koefisien korelasi ganda menghasilkan nilai $\mathrm{F}_{\text {hitung }}$ sebesar 322,629 pada taraf Sig 0,000 yang berarti sangat signifikan. Hal ini menunjukkan bahwa ada pengaruh yang signifikan antara sikap siswa $\left(\mathrm{X}_{2}\right)$ terhadap hasil belajar matematika (Y).

Artinya jika sikap siswa pada matematika tinggi maka hasil belajar matematika tinggi dan jika sikap siswa pada matematika rendah maka hasil belajar matematika rendah. Hasil ini sejalan dengan Susilo (2015), ${ }^{11}$ dengan hasil penelitian menunjukkan, ada pengaruh positif dan signifikan antara sikap siswa pada matematika terhadap hasil belajar matematika sebesar 0,475 dan tergolong cukup tinggi dengan koefisien determinasi 0,2256, sehingga dapat dikatakan sikap siswa pada matematika berpengaruh $22,56 \%$ terhadap hasil belajar matematika, dan 77,44\% dipengaruhi oleh faktor lain.

Tabel ANOVA ganda antara $\mathrm{X}_{2}$ terhadap $\mathrm{Y}$

\section{ANOVA $^{a}$}

\begin{tabular}{|l|l|l|l|l|c|c|}
\hline \multicolumn{2}{|c|}{ Model } & \multicolumn{1}{c|}{ Sum of Squares } & df & Mean Square & F & Sig. \\
\hline 1 & Regression & 1464.356 & 1 & 1464.356 & 322.629 & $.000^{\mathrm{b}}$ \\
\hline & Residual & 444.804 & 98 & 4.539 & & \\
\hline & Total & 1909.160 & 99 & & & \\
\hline
\end{tabular}

\section{KESIMPULAN}

1. Terdapat pengaruh yang signifikan kemampuan menghafal al-Qur'an terhadap hasil belajar matematika siswa. Hal ini berdasarkan pada hasil analisis data yang diperoleh nilai

11 Susilo, T. A. B., \& Agustin, I., "Pengaruh Sikap Siswa pada Matematika...", h. 9-16. 
$\mathrm{F}_{\text {hitung }}=347,562$ dan sig $=0,000$. Nilai sig lebih kecil dari 0,05. Maka hipotesis yang diajukan "terdapat pengaruh positif antara kemampuan menghafal al-Qur'an dengan hasil belajar matematika" dapat diterima.

2. Terdapat pengaruh yang signifikan sikap siswa terhadap hasil belajar matematika. Hal ini berdasarkan pada hasil analisis data yang diperoleh nilai $\mathrm{F}_{\text {hitung }}=322,629$ dan sig $=0,000$. Nilai sig lebih kecil dari 0,05. Maka hipotesis yang diajukan "terdapat pengaruh positif antara sikap siswa dengan hasil belajar matematika" dapat diterima.

3. Terdapat pengaruh yang signifikan interaksi kemampuan menghafal al-Qur'an dan sikap siswa dengan hasil belajar matematika. Hal ini berdasarkan pada hasil analisis data yang diperoleh $\mathrm{F}_{\text {hitung }}=191,882$ dan sig = 0,000. Nilai sig lebih kecil dari 0,05. Maka terdapat pengaruh positif antara kemampuan menghafal al-Qur'an $\left(\mathrm{X}_{1}\right)$ dan sikap siswa $\left(\mathrm{X}_{2}\right)$ secara bersamasama dengan hasil belajar matematika (Y)", dapat diterima.[] 


\section{DAFTAR PUSTAKA}

Arif Rohman, Memahami Pendidikan dan Ilmu Pendidikan, (Yogyakarta: Laksbang Mediatama, 2009), 223.

Anwar, K., \& Hafiyana, M. (2018). Implementasi Metode ODOA (One Day One Ayat) dalam Meningkatkan Kemampuan Menghafal Al-Qur'an. Jurnal Pendidikan Islam Indonesia, 2(2), 181-198.

Bassette, L. P. (2004). An assessment of the attitudes and outcomes ofstudents enrolled in developmental basic mathematics classes atPrince George's community college (Doctoral dissertation). VirginiaPolytechnic Institute and State University.. Diunduh dari http://academia.edu/

Erman Suherman ,dkk, Strategi Pembelajaran Matematika Kotemporer, Bandung: FMIPA Universitas Pendidikan Indonesia.

Hartono. SPSS 16. (2008). Analisis Data Statistika dan Penelitian. Yogyakarta: Pustaka Pelajar.

Ilmia, M. (2016). Hubungan antara hafalan Al-Qur'an dengan prestasi belajar siswa kelas IV Sekolah Dasar Islam Assalam Malang (Doctoral dissertation, Universitas Islam Negeri Maulana Malik Ibrahim)

Jayanti, L. F. (2019). Pengaruh Motivasi Menghafal Al-Qur'an Terhadap Prestasi Belajar Siswa Mata Pelajaran Al-Qur'an Hadist Ma Darul Falah Bendiljati Kulon Tahun 2018/2019.

Neni, M. A. (2017). Pengaruh Menghafal Al-Qur'an Terhadap Kecerdasan Emosional Santri Di Pondok Pesantren Al-Qur'an Muhammad Thoha Alfasyni Bogor. Tadbir Muwahhid, 4(1).

Nuryanti, Lusi. (2008). Psikologi Anak, Jakarta: PT. Indeks.

Romi, R., Arief, Y., \& Siregar, J. (2018). Perbedaan Prestasi Belajar 
Matematika Antara Siswa Yang Mengikuti Dan Tidak Mengikuti Program Menghafal Al-Qur'an. An-Nafs, 12(1), 1-11.

Syah, M. (2003). Psikologi Belajar. Jakarta: PT. Raja Grafindo Persada.

Sa'dulloh, 2008. 9 Cara Praktis Menghafal Al-Qur'an, Jakarta: Gema Insani.

Sudjana, N. (2011). Penelitian Hasil Proses Belajar Mengajar. Bandung: Remaja Rosdakarya.

Susilo, T. A. B., \& Agustin, I. (2015). Pengaruh Sikap Siswa pada Matematika terhadap Hasil Belajar Matematika di SMP. Jurnal Pendidikan Matematika, 3(1), 9-16. 